\title{
CAMINHOS DO CATIVEIRO: a experiência de escravos e libertos em Castro (1800-1830)
}

PATHS OF CAPTIVITY: the experience of slaves and freedmen in Castro (1800-1830)

\section{Bruna Marina PORTELA ${ }^{\bullet}$}

Resumo: Este artigo analisa a configuração de uma comunidade escrava em Castro, São Paulo, durante as três primeiras décadas do século XIX. Busca compreender o que significou para esses cativos viver em uma vila voltada quase que exclusivamente para a criação e o comércio de animais. Para isso, foi utilizado como principal corpo documental inventários post-mortem de proprietários de escravos e, além deles, Listas Nominativas de Habitantes e outros documentos oriundos do poder judiciário. Através desta documentação, foi possível seguir a trajetória de alguns escravos e examinar aspectos da constituição de suas famílias e de seus vínculos com a vida agropastoril. Suas experiências semelhantes, fosse conduzindo tropas, cuidando do gado ou buscando uma vida melhor fora da vila de Castro, após receberem sua liberdade, fizeram com que configurassem uma comunidade escrava com ideais, interesses e visões de mundo particulares.

Palavras-chave: Escravidão; Liberdade; Comércio de animais; Mobilidade espacial.

\begin{abstract}
This article analyzes the configuration of a slave community in Castro, São Paulo, during the first three decades of the nineteenth century. It seeks to understand what it meant for these captives to live in a town directed almost exclusively towards raising and trading of animals. For that reason, slave owner's postmortem inventories were used as the main documentary body, and beyond them, Nominative Lists of Inhabitants and other documents from the judiciary. Through this documentation, it was possible to follow the trajectory of some slaves and examine aspects of the constitution of their families and their links with the agro-pastoral life. Their similar experiences, leading troops, taking care of livestock or seeking a better life outside the village of Castro, after receiving their freedom, it was made possible to shape a slave community with ideals, interests and particular world views.
\end{abstract}

Keywords: Slavery; Freedom; Animal trade; Spatial mobility.

\section{Uma povoação dos Campos Gerais}

A região de Castro ficou conhecida na historiografia por seu envolvimento na criação de animais, justamente por pertencer à chamada rota dos tropeiros e também por estar situada em um local geograficamente propício a este tipo de atividade. Para viabilizar a comunicação com esta região, em 1730 foi aberto o caminho ligando Viamão à Sorocaba (TRINDADE, 1992, p. 30). A partir de então, a integração do sul com o restante da colônia se intensificou uma vez que esta estrada, que ficou conhecida como Caminho do Viamão, ligava as terras gaúchas às paulistas, passando pelos Campos Gerais, o que incluía Castro, até chegar a Sorocaba. Daí partiam outros caminhos para diferentes localidades da América portuguesa, facilitando o escoamento da produção sulina.

Com a abertura do caminho do Viamão muitas povoações foram surgindo e prosperando ao longo da estrada, como foi o caso de Castro, que em 1730, ano de abertura de tal caminho, tinha a

\footnotetext{
- Mestre em História - Doutoranda - Setor de Humanas - UFPR - Univ. Federal do Paraná - Rua General Carneiro, 460, CEP: 80060-150, Curitiba, PR, Brasil. E-mail: portela.bruna@ gmail.com
} 
denominação de Pouso do Iapó. Porém, a ocupação desse território remonta aos primeiros anos do século XVIII quando sesmarias foram distribuídas na região. As terras foram adquiridas principalmente por proprietários vindos de Paranaguá, Santos e São Paulo, sendo que uma boa parte deles não residia na sesmaria recebida, ou seja, eram proprietários absenteístas, que contavam apenas com um fazendeiro e escravos para fazer prosperar a terra ${ }^{1}$.

Na primeira metade do século XIX, período que aqui nos interessa mais diretamente, já não podemos falar apenas no caminho do Viamão como a única via para o escoamento do gado. Do Rio Grande do Sul surgiram outros caminhos, como o que saía dos campos de Vacaria, menos longo e com melhores condições para os viajantes, que se encontrava com o caminho do Viamão na região de Lages. Em fins da década de 1840 é aberta a Estrada das Missões ou de Palmas, que passava pelos recém descobertos campos de Guarapuava até chegar à região de Ponta Grossa, de onde seguia pelo caminho já existente até Sorocaba (TRINDADE, 1992, p. 33-35). Mesmo com todas as alterações nos caminhos, Castro não deixou de estar na rota dos tropeiros, desde a primeira metade do século XVIII até finais do XIX, quando o tropeirismo começou a entrar em decadência.

Em 1770, Afonso Botelho, Chefe de Expedições Militares, providenciou para que fossem criadas duas freguesias nos Campos Gerais, a de Sant'anna do Iapó (Castro) e a de Santo Antonio do Registro (Lapa). Começaram então a ser nomeadas as primeiras autoridades da freguesia, que em 1780 contava com 688 habitantes, dos quais 479 eram livres e 209 escravos (DINIZ, 2003, p.34). Já em 1789, foi elevada à categoria de vila e denominada Vila Nova de Castro, em homenagem ao Secretário de Estado dos Negócios Ultramarinos de Portugal, Martinho de Melo e Castro, atuante nesta pasta entre 1785 e 1790 (FERREIRA, 2006, p. 81).

Entre os anos de 1800 e 1830, Castro manteve sua população em uma média de 4.500 habitantes, chegando a 5.036 pessoas em 1810 e 3.787 indivíduos em 1824 (COSTA E GUTIERREZ, 1985, p. 50, 76, 102, 130 e 162). A capitania de São Paulo como um todo, neste mesmo período, aumentou sua população de 169.544 para 287.645 habitantes (MARCÍLIO, 2000,

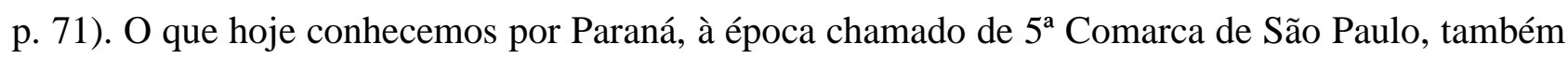
aumentou sua população nas primeiras décadas do século XIX. Entre 1810 e 1830, os habitantes dessa região passaram de 27.589 para 36.701 pessoas, sendo que a região dos Campos Gerais ainda era a menos povoada (WESTPHALEN, 1997, p. 26).

No início do século XIX, Castro já era uma vila reconhecida por seu envolvimento nas atividades tropeiras e pecuaristas, e a ampliação do mercado interno ocorrida nesses anos favoreceu o desenvolvimento dessas atividades. Uma das alavancas para que tal ampliação acontecesse foi a chegada da corte portuguesa ao Rio de Janeiro em 1808. Este evento proporcionou o estabelecimento de relações mercantis com diversas regiões do Brasil, incluindo aí o sul da América portuguesa que abastecia a corte de gado vacum, cavalar e muar, fosse para transporte, vestuário ou 
alimentação (MARCONDES, 2001, p. 41-42).

Mas não era apenas a corte que o sul do Brasil abastecia; Minas Gerais, mais intensamente no século XVIII - quando a atividade da mineração ainda trazia algum lucro para aquela Capitania e necessitava do gado muar para transporte - e as lavouras de café em São Paulo, prósperas no início do século XIX, também se faziam valer dos animais vindos pelos caminhos do sul. Minas Gerais, porém, também se dedicava à criação de animais e à produção de gêneros para o abastecimento interno, principalmente o sul da capitania, que, no início do século XIX, já começava a fazer concorrência com o gado vindo dos Campos Gerais e do Rio Grande de São Pedro do Sul.

Os habitantes dos Campos Gerais desempenhavam também o papel de mediadores, viajando para o Rio Grande de modo a comprar os animais, trazendo-os para suas terras a fim de descansálos e engorda-los para, posteriormente, os revender em Sorocaba. Além disso, também se dedicavam à criação de gado, conforme a historiografia e também nossas fontes demonstraram.

A vila de Castro se viu cortada por um caminho que, além de integrar a região ao restante da colônia, também estabeleceu redes pessoais e comerciais de interdependência, que se mantiveram por séculos a fio. Essas redes trouxeram novas possibilidades para as pessoas que ali residiam, que além do cultivo da terra e da criação de animais, poderiam se envolver nas atividades tropeiras, servindo de intermediários na compra do gado no Rio Grande do Sul, sua invernagem nos Campos Gerais e a venda nas feiras de Sorocaba. Além disso, por ser uma região de passagem obrigatória para os tropeiros, a venda de fazendas secas e de outros gêneros também se tornava um bom negócio.

No início do século XIX Castro era uma vila bastante próspera e, como consequência, boa parte dos proprietários possuíam escravos, alguns com números bastante próximos aos senhores da região do Vale do Paraíba. Através dos dados levantados por Costa e Gutiérrez nas Listas Nominativas de Habitantes de Castro dos anos de 1804, 1810, 1816, 1824 e 1830 chegamos ao percentual de escravos na população em geral (COSTA; GUTIERREZ, 1985, p. 50, 76, 102, 130 e $162)^{2}$. Durante os anos mencionados o percentual variou de 21,42\% em 1804, chegando a $26,98 \%$ em 1824. Números bastante acima dos encontrados para Curitiba e São José dos Pinhais neste mesmo período, que variou de 10,6\% em 1830, tendo seu maior índice em 1804 com 17,1\% de escravos no total da população (WESTPHALEN, 1997, p. 33).

Analisando inventários post-mortem de proprietários de Castro e alguns outros tipos de processos judiciais conseguimos informações sobre alguns escravos que viveram nessa vila no início do século XIX. Alguns escravos pertencentes a senhores de Castro, tiveram a oportunidade de viajar junto de seus proprietários para negociar o gado e, assim, alargar os seus laços de sociabilidade 


\section{Ainda no cativeiro}

Viver na condição de escravo em uma vila como Castro certamente tinha as suas peculiaridades. As experiências pelas quais os cativos dessa comunidade passaram foram, sem dúvida, diferentes das vivenciadas pelos cativos que trabalhavam nas plantations do Vale do Paraíba, por exemplo. Neste artigo analisaremos situações vividas pelos escravos de nossa amostra, procurando mostrar o que era ser cativo numa "zona de trânsito", como Cecília Westphalen definiu a região onde atualmente é o estado do Paraná (WESTPHALEN, 1957).

Começaremos pelo grupo de escravos que vivia na fazenda Pitangui que pertenceu à Companhia de Jesus e, em 1806 (ano da feitura do inventário), era administrada por Atanagildo Pinto Martins e de propriedade da Coroa portuguesa. Quando o inventário foi feito Pitangui contava com 31 escravos e é provável que alguns deles tivessem convivido com os jesuítas, uma vez que sete deles estavam com mais de cinquenta anos: Gertrudes, a mais velha, 93 anos, viúva; Páscoa, de 79 anos, também viúva; Domingas, de 81 anos, casada; Ignácia, de 52 anos, também casada; Joaquim, de 67 anos, casado; Vicente, de 69 anos, casado; e João Gomes, de 86 anos de idade, de quem não temos informações se era casado, solteiro ou viúvo.

Os bens descritos no inventário remetem ao passado religioso da propriedade. São arroladas várias imagens de santos e santas, uma capela de pedra e barro avaliada pelo valor considerável de $200 \$ 000$ (duzentos mil réis), livros velhos de catecismo, presépios, vidrinhos de santos óleos, entre outros paramentos religiosos. Além disso, há uma relação de bens pertencentes à Senhora do Rosário dos Pretos e à Santa Bárbara. Certamente a convivência com os jesuítas e o catolicismo, influenciou a religiosidade dos escravos, que seguiam as práticas aprendidas com seus senhores, como atesta o fato de uma imagem de Nossa Senhora da Piedade, arrolada no inventário, pertencer a uma escrava e por isso não ter sido atribuído nenhum valor.

$\mathrm{Na}$ própria vila de Castro temos outros exemplos de grupos religiosos donos de grandes fazendas de gado e de muitos escravos, como os Carmelitas, possuidores da fazenda Capão Alto, entre outras propriedades rurais. Na década de 1860 os mais de 200 escravos que viviam em Capão Alto foram arrendados para comerciantes paulistas e, consequentemente, teriam que ser levados para trabalhar nas fazendas de café da província de São Paulo. Os cativos, acostumados a uma certa autonomia na condução de suas vidas - uma vez que não tinham na fazenda um senhor para vigiálos, mas sim um administrador, que também era escravo - se recusaram a seguir com os comerciantes. Apesar da resistência, quem acabou vencendo foram os frades carmelitas e a Casa Comercial, que conseguiram realizar a transação mesmo com impedimentos legais ${ }^{3}$. A Ordem do Carmo, assim como as demais Ordens existentes na segunda metade do século XIX, estavam na iminência de terem seus bens alienados pelo governo imperial, situação semelhante pela qual os jesuítas haviam passado um século antes. Os carmelitas, porém, puderam amenizar os prejuízos, 
realizando transações como a de Capão Alto, que lhe renderam alguns contos de réis.

No ano de 1810, alguns escravos de Pitangui passaram pela mesma situação que os de Capão Alto. A Lista Nominativa de Habitantes desse ano nos informa que quatro cativos foram mandados para a cidade de São Paulo, por ordem de um senhor cujo nome está ilegível no documento, mas que provavelmente era o governador da província de São Paulo ou outra autoridade importante, uma vez que o nome vem precedido de "Ilmo. Sr."4 Camillo, Manoel, Cláudia e Maria já estavam na fazenda Pitangui há muito tempo. As duas mulheres muito provavelmente nasceram na propriedade já que estavam com 10 e 13 anos, respectivamente, e em 1804 já constavam na Lista Nominativa, ainda crianças, com quatro e sete anos. Também é possível que Camillo e Manoel tenham nascido em Pitangui, pois em 1798 já constavam os dois na Lista, o primeiro com nove anos de idade e o segundo com $12^{5}$. Podemos imaginar então o quão difícil foi para esses escravos deixar um lugar que viveram desde pequenos para seguir para uma cidade como São Paulo, bem diferente da realidade a que estavam acostumados.

Provavelmente os escravos mais velhos eram a base da comunidade escrava que se formou em Pitangui, gerando filhos, netos e bisnetos. Havia um número muito equilibrado de homens e mulheres em 1806, sendo 16 do sexo masculino e 15 do feminino. O número de crianças também era significativo: 12 cativos com até 15 anos de idade. Além disso, o administrador da fazenda, Atanagildo Pinto Martins, possuía mais alguns escravos, conforme veio demonstrado na Lista Nominativa de 1804, que representavam também possibilidades de união entre eles e os escravos pertencentes a Real Coroa ${ }^{6}$. Nesse ano Atanagildo contava com quatro escravos: Maria, crioula, seis anos; Ignácio, crioulo, 14 anos; Esperança, crioula, 26 anos e Francisca, uma africana procedente de Benguela, com 64 anos e a única casada entre os quatro. Vale ressaltar que a única africana entre os escravos, tanto do administrador da fazenda como dos pertencentes à Coroa portuguesa, era Francisca. Ou seja, também em Pitangui os crioulos eram a grande maioria, corroborando o quadro geral encontrado para Castro no início do século XIX.

Era, portanto, uma unidade escravista estável que certamente era composta por famílias. A estabilidade dos escravos e a presença de núcleos familiares são reforçadas por uma informação encontrada somente neste inventário. Estão arrolados entre os bens de raiz algumas senzalas, inclusive com a indicação de quais escravos moravam nelas. A escrava Gertrudes, de quem já falamos, morava em uma das senzalas junto com Salvador, um cativo de 38 anos e que, possivelmente, era filho de Gertrudes, uma vez que ela tinha 93 anos e consta como viúva. Das cinco senzalas arroladas no inventário, quatro pertenciam aos escravos com mais de cinquenta anos. Apenas uma aparece como pertencente ao escravo Ângelo, que estava com 30 anos, casado e tinha a profissão de ferreiro.

O fato de viverem há mais tempo na fazenda pode ter sido o motivo desses escravos terem 
conseguido o privilégio de ter uma habitação para si e sua família. No caso do cativo de 30 anos, é provável que sua profissão tenha lhe dado o prestígio necessário para ter direito a uma senzala separada dos demais, pois o ofício da ferraria, além de ser extremamente útil para os afazeres da fazenda, também conferia ao escravo um valor mais alto, devido sua qualificação.

Porém, esses escravos que possuíam senzalas tinham mais um ponto em comum: eram casados ou viúvos, segundo a Lista Nominativa de 1804, com exceção de João Gomes, sobre quem não conseguimos informações. Robert Slenes, em seu livro Na Senzala, uma flor, dedica parte de seu estudo a arquitetura das senzalas e associa o casamento a melhores condições de moradia (SLENES, 1999, p. 149-180). Utilizando relatos de viajantes, esse autor chega à conclusão de que os cativos casados teriam o privilégio de ocupar um espaço separado dos outros, fosse num cubículo dentro da construção em que ficavam todos os escravos, ou então em um barraco separado (SLENES, 1999, p. 159).

Pela descrição do inventário, a senzala dos escravos de Pitangui eram barracos separados, pois, existia um valor atribuído para cada uma delas. As que pertenciam aos escravos Ângelo, João Gomes e Joaquim foram avaliadas em 5\$000 (cinco mil réis), a que Gertrudes e Salvador ocupavam em 3\$000 (três mil réis) e, finalmente, a de Páscoa em 2\$000 (dois mil réis). A descrição das senzalas mostra que nenhuma delas tinha janelas, apenas portas, algumas com fechaduras. Através dos relatos e imagens feitos pelos viajantes, Slenes também observa a falta de janelas nas habitações e, além disso, o pouco espaço que havia dentro delas (SLENES, 1999, p. 160). Ao que parece, no que diz respeito ao tamanho das senzalas, as construções de Pitangui se diferenciavam das analisadas por Slenes. A menor e a mais barata das habitações, pertencente à escrava Páscoa, tinha duas portas; a de Joaquim tinha quatro e a de Gertrudes e Salvador, cinco. Isto significa que não deveriam ser espaços muito pequenos.

Os outros escravos da fazenda deveriam dividir a mesma senzala, com espaço suficiente para abrigar, pelo menos, vinte pessoas, uma vez que Pitangui contava com 31 cativos. Existem outras construções avaliadas no inventário que poderiam servir de moradia dos escravos, como um "rancho coberto de telhas com sua porta e fechaduras", avaliado em $20 \$ 000$ (vinte mil réis).

Slenes afirma, através dos relatos dos viajantes, que as senzalas eram comumente trancadas à noite para impedir as fugas (SLENES, 1999, p. 164-165). Em Pitangui, as únicas habitações que aparecem com fechaduras são as de Joaquim e de João Gomes e, ambas em apenas uma das portas, o que não impediria a fuga destes escravos. A região analisada por Slenes, o Vale do Paraíba paulista, se dedicava à produção para exportação e contava com um grande número de cativos, a maioria africanos. Em Castro os escravos eram majoritariamente crioulos, o que significa que estavam ali há algumas gerações e que mantinham vínculos familiares. Sabemos que a constituição de famílias também ocorria nas áreas de plantation, como o próprio Slenes demonstrou (SLENES, 
1999, p. 69-130), mas, no caso de Pitangui, pela idade avançada dos escravos, pelo número de casados e viúvos (11 pessoas) e também pelo grande número de crianças no grupo de escravos, podemos inferir que estavam ali há algumas gerações e possuíam fortes vínculos familiares. Aliado a esse fato, observamos a relativa autonomia que esse grupo de cativos tinha na fazenda, uma vez que era administrada por um arrendatário; além disso, alguns escravos, como mostramos, possuíam senzalas próprias e, como veremos adiante, eles poderiam ter a possibilidade de produzir em benefício próprio e vender o excedente. Esses, portanto, podem ser os motivos para que as senzalas não precisassem de fechaduras. Os escravos de Pitangui possuíam uma situação estável e talvez não lhes interessasse intentar uma fuga, muitas vezes para o desconhecido.

Através do inventário de bens da fazenda Pitangui podemos nos aproximar um pouco mais do cotidiano de trabalho nas fazendas de criação. Isso porque são descritos vários instrumentos de carpintaria, ferraria e lavoura, o que dá margem para pensarmos que Pitangui conseguia suprir boa parte de suas necessidades no âmbito da própria fazenda. São quase 20 ferramentas de ferreiro arroladas, além de uma casa que servia de ferraria e, certamente, era comandada pelo escravo Ângelo, o qual, como já informamos, vem descrito no inventário como ferreiro. Sabemos então que ferramentas como enxadas, foices e machados, utilizados para a agricultura, além de arreios e outros instrumentos usados na pecuária, eram produzidos na própria fazenda, que também contava com uma carpintaria, essencial para a produção das ferramentas citadas e para a fabricação de móveis e outros objetos. Na propriedade havia ainda um quintal com algodão e 83 ovelhas das quais devem ter extraído a arroba e meia de lã arrolada entre os bens. Tanto a lã como o algodão constituíam matéria-prima para a confecção de roupas e de apetrechos para montaria, como o coxonilho, uma manta de lã colocada sobre o lombo do animal.

Pitangui contava também com um grande número de animais, que chegaram a mais de 700 . No entanto, quase 500 deles eram cavalares, os menos procurados pelos compradores, fosse na feira de Sorocaba ou em outras regiões (PETRONE, 1976, p. 21-22). O gado vacum, que tinha um bom mercado para venda, somava pouco mais de 100 cabeças e os muares, os mais vendidos, eram apenas dois. É possível que quando os bens foram avaliados, Pitangui tivesse acabado de fazer negócio e vendido uma boa quantidade de gado ou então que obtivessem lucro para fazenda não apenas da pecuária, mas também da agricultura e até da venda de ferramentas. Afinal, possuíam uma ferraria e um escravo especializado nessa profissão, o único entre os 314 cativos de nossa amostra e também a única propriedade em que uma ferraria é arrolada entre os bens de raiz.

Além disso, sabemos que o caminho das tropas passava pela fazenda Pitangui (WESTPHALEN, 1957, p. 50) e muitos tropeiros e viajantes os quais por ali transitavam paravam para frequentar a capela de Santa Bárbara, erguida pelos jesuítas (LOPES, 2001, p. 10-11). Provavelmente, mesmo após a expulsão da Companhia de Jesus, os tropeiros continuaram a passar 
pelas terras de Pitangui, o que possibilitava a venda de tudo o que lá era produzido. Inclusive os escravos poderiam se valer dessa vantagem e vender o excedente de sua produção própria, como analisaremos melhor na próxima seção.

Trabalho, portanto, era o que não faltava para os 31 escravos de Pitangui. A pecuária necessitava de menos trabalhadores do que as outras atividades. Pelo número de animais existentes em Pitangui, em torno de 750, é possível que apenas um ou dois escravos dessem conta do serviço. As 83 ovelhas, além do cuidado comum aos outros animais, precisavam ser tosadas para então a lã ser fiada e transformada em cobertores, mantas e outros objetos, provavelmente produzidos pelas mulheres. Também elas deveriam ser as responsáveis pelos serviços domésticos como o preparo de comida, além da confecção de roupas, uma vez que a fazenda plantava algodão. A agricultura também deveria absorver boa parte da mão-de-obra dos escravos, tanto homens como mulheres, já que era ela quem iria garantir a subsistência tanto das pessoas como também dos animais.

Para a fazenda Pitangui não conseguimos encontrar nenhuma evidência de que os cativos estivessem envolvidos nas viagens para compra e venda do gado. Se a fazenda mantivesse essa prática, talvez fosse o seu arrendatário, Atanagildo, o responsável por levar os animais até os compradores, podendo, inclusive, contar com a ajuda de algum escravo para isso. Mas pela localização estratégica de Pitangui, passagem de muitos tropeiros que seguiam para Sorocaba, é muito provável que os compradores fossem até ela e não comprassem apenas gado, mas também os outros produtos ali fabricados.

A comunidade escrava de Pitangui conseguiu se manter unida pelo menos até 1810, quando então alguns cativos seguiram para São Paulo, como também foi o caso dos escravos de Capão Alto e de tantos outros igualmente moradores na vila de Castro. Em nossos documentos é bastante comum que escravos antes pertencentes a uma mesma unidade escravista sejam separados após a partilha de bens. Alguns ainda permaneciam em poder da mesma família, mas quando seus senhores tinham alguma dívida, muitos eram leiloados e tinham então que seguir para a casa de um novo proprietário.

Para os escravos Rita e Miguel a partilha de bens de seu falecido senhor lhes trouxe uma separação que não deve ter sido fácil. Os dois escravos eram casados e viviam em Castro na propriedade de Ignácio Rodrigues da Silva, falecido em 1800. Junto com o casal, viviam mais quatro escravos, sendo três crianças, de sete, cinco e um ano e meio de idade, e o africano Manoel, de 45 anos e procedente de Benguela. A informação de que Rita e Miguel eram casados aparece no próprio inventário, o qual informa também que Miguel era africano, procedente de Benguela, assim como Manoel. Rita era crioula e tinha 25 anos, ou seja, era 15 anos mais jovem que seu marido. Esse era, portanto, um casamento exogâmico, o que certamente contribuiu para a crioulização dos cativos da região. 
Após feita a avaliação de bens, em 1800, nasceu o escravo Braz, que foi avaliado em 1805 e já estava com quatro anos. Presumimos que fosse filho de Rita e Miguel, afinal eles eram o único casal existente na propriedade e Manoel, mesmo que mantivesse algum tipo de relacionamento conjugal, certamente não era com uma escrava de Ignácio Rodrigues da Silva, pois além de Rita, as outras mulheres ainda eram crianças. É possível que essas crianças também fossem filhos do casal, mas existe também a possibilidade de que tenham sido comprados.

Como todos os filhos de Anna Maria Teixeira, viúva de Ignácio, eram menores, os bens foram divididos meio a meio, ou seja, os herdeiros tinham uma parte de tudo o que ficou para ela. Por exemplo, o valor do escravo Manoel foi dividido entre a viúva e os três filhos. Pensando no que faria logo em seguida ao término da partilha de bens, Anna Maria solicitou ao juiz de órfãos que fosse feita uma troca para que pudesse ficar com o valor dos escravos Rita e Miguel por inteiro. Dessa forma não teria impedimento para sair da vila de Castro. E foi exatamente o que ela fez. Em 1805 há uma declaração do tutor dos menores, afirmando que a viúva "acha-se ausente para as partes do sul, para onde foi fugitiva, levando consigo seus filhos órfãos menores Ignácio, Antonia e Maria, deixando todos os bens pertencentes aos ditos órfãos desamparados" ${ }^{8}$. A viúva não poderia levar os bens pertencentes a seus filhos e por isso solicitou a troca de bens, o que lhe permitiu a ida para o chamado Continente do Sul.

Mas, e o casal de escravos Rita e Miguel nessa história? Os dois, pelo que se sabe, foram os únicos que seguiram com sua senhora. Todos os outros foram arrematados em leilão por diferentes senhores, inclusive o crioulo Braz, possível filho do casal, comprado por um padre. Vemos então que a mobilidade espacial comum a essa região nem sempre trazia boas experiências para os cativos. A busca por uma vida melhor, por parte de sua senhora, resultou para os dois numa separação provavelmente nada fácil. Sabemos que a viúva e seus filhos permaneceram no Rio Grande de São Pedro do Sul pelo menos até o ano de 1831, quando o último de seus filhos requereu a parte que lhe cabia na herança, ainda nas mãos do tutor em Castro. Sobre Rita e Miguel, nada mais sabemos.

Se por um lado para alguns escravos a permanência na vila de Castro lhes atenuava a dor do cativeiro, uma vez que isso lhes permitia ficar junto de suas famílias, para outros quanto mais longe estivessem melhor. Foi o caso de três escravos pertencentes a José Rodrigues Betim, que aproveitaram a morte de seu senhor e o momento da partilha dos bens para realizar uma fuga. Segundo consta no inventário, os três cativos, que infelizmente não sabemos os nomes, fugiram para a vila de Lages, na época também pertencente à capitania de São Paulo ${ }^{9}$. Um credor de Betim denuncia que os bens do falecido estavam sem nenhum cuidado e que muita coisa estava se deteriorando, o que deve ter facilitado a fuga dos escravos. Os três levaram consigo cavalos, bestas e potrancas, dos quais venderam alguns e outros certamente utilizaram para chegar até Lages; além 
dos animais, levaram também uma arma de fogo. Quem nos dá essas informações é o inventariante Antonio Rodrigues Penteado, genro do falecido Betim.

Os três escravos foram bastante astutos e aproveitaram o momento confuso, a avaliação e a partilha de bens, para realizar uma fuga ousada, uma vez que levaram consigo quase 20 animais e uma arma de fogo, mostrando o quão caótica estava a situação, uma vez que os herdeiros não evitaram a fuga de sua herança. Não sabemos com certeza o que aconteceu com os cativos fujões. No inventário são avaliados 12 escravos e na partilha os 12 continuam presentes. É possível que os três escravos tenham sido capturados e trazidos de volta para a fazenda, mas, outra possibilidade é a de que eles nem tenham sido avaliados, já que no testamento de Betim este afirma ter 14 escravos. Apesar da conta não bater, pois 14 menos os três fugitivos seriam 11 e não 12, podemos pensar que esses cativos fugiram antes mesmo de serem avaliados. Se esse for o caso, pelo menos a princípio a fuga funcionou.

Devemos lembrar que Lages ficava na rota do caminho das tropas as quais seguiam para o continente do sul e José Rodrigues Betim era criador de animais e mantinha relações com pessoas daquele lugar. A possível mobilidade espacial usufruída pelos escravos desse senhor, quando o seguiam nas viagens para negociação do gado, pode ter lhes facilitado a fuga e até a venda dos animais, atividade a qual já estavam habituados. A experiência adquirida enquanto cativos de uma região voltada para a criação e venda do gado lhes trouxe novos conhecimentos e habilidades dos quais fizeram uso para tentar mudar o rumo de suas vidas. Aqui devemos nos remeter ao conceito de "experiência" elaborado por Edward Thompson. Para o autor, a experiência é produto da cultura herdada pelos homens e é, em grande parte, determinada pelo meio material no qual o sujeito está inserido. Por outro lado, a experiência elaborada enquanto consciência social, também vai determinar esse meio material, podendo modificá-lo (THOMPSON, 1987, p. 9-14). É uma via de mão dupla, conflituosa, na qual os indivíduos estão todo tempo se relacionando e buscando estratégias para melhorar as suas condições de existência. É o que podemos observar com o exemplo dos três escravos fugitivos que usaram o aprendizado que obtiveram no cativeiro para depois fugir dessa condição. O que antes era visto com bons olhos pelos senhores, ou seja, cativos trabalhando para eles nas viagens de compra e venda do gado, depois poderia se tornar um problema.

A mobilidade espacial comum a essa região poderia tanto trazer benefícios como perdas para os escravos, conforme demonstramos com os exemplos acima. $\mathrm{O}$ fato de Castro, assim como toda a

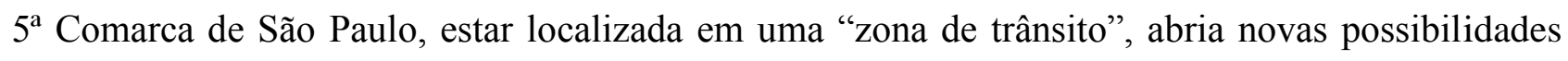
para seus moradores, que poderiam sair em busca de melhores oportunidades em outras vilas paulistas ou no Rio Grande de São Pedro do Sul. Senhores e também escravos, além da população livre não escravista, mantinham contatos com pessoas de outras partes da América portuguesa, 
alargando as possibilidades de novos lugares para se estabelecerem. Ou então, no caso dos escravos de Pitangui, aproveitavam a conveniência de estarem em uma "zona de trânsito" para vender seus produtos aos tropeiros que por ali passavam.

A seguir veremos como os escravos souberam aproveitar as oportunidades oferecidas pela vivência em uma área como os Campos Gerais a seu favor. Falaremos da produção excedente dos cativos, que lhes permitia um pequeno acúmulo financeiro.

\section{Economia interna dos escravos}

Entraremos agora num assunto ainda delicado para a historiografia da escravidão. Muito já se debateu sobre o tema e certamente muita coisa ainda existe para ser analisada. Para este artigo utilizamos informações extraídas dos inventários e que indicam a existência de uma economia interna dos escravos em algumas unidades escravistas. Mas antes de entrarmos nas fontes, falaremos brevemente sobre as discussões que já existem sobre o tema.

Nos anos 1970 Ciro Cardoso consolidou a expressão "brecha camponesa" e foi acompanhado por autores como Jacob Gorender. Para esses dois autores a própria expressão já explica do que se tratava a produção independente dos escravos: uma brecha, uma abertura, concedida pelos senhores aos cativos com a intenção de controlá-los melhor, tentando prendê-los de alguma maneira à sua propriedade. Gorender acreditava que a produção dos escravos em nada influenciava as relações escravistas e mantinha a situação de domínio dos senhores sobre os primeiros. Cardoso, em trabalho de 1975, pensava da mesma maneira que Gorender, mas, em 1987, esse autor repensa a questão e confere à produção excedente dos cativos uma maior importância dentro das relações escravistas (GORENDER, 1985; CARDOSO, 1979; CARDOSO, 1987).

Estudos mais recentes, como o do historiador Robert Slenes, estão pautando suas análises na historiografia norte-americana, a qual usa a expressão "economia interna dos escravos" para designar todos os meios que os escravos tinham de acumular algum pecúlio, não apenas a agricultura, mas também a caça e até o furto (SLENES, 1999, p. 197-208). Essa vertente historiográfica pensa a produção dos escravos como uma via de mão dupla que colocava em jogo não apenas os interesses dos senhores, mas também o dos cativos, que sabiam aproveitar essa concessão que lhes era feita.

Nos inventários aqui analisados encontramos alguns indícios de que os escravos de Castro também conquistaram o direito de possuir roças para sua subsistência e também para a venda do excedente. É o caso do cativo de nome José, pertencente a Joaquim Carneiro Lobo, que aparece como credor no inventário de Francisco Carvalho de Oliveira. O falecido, morto em 1806, devia $1 \$ 920$ (mil novecentos e vinte réis) a José proveniente de milho que havia comprado. Como pagamento da dívida foi dado ao escravo três carneiros. 
Em nossas fontes temos também o inventário de Joaquim Carneiro Lobo, falecido em 1830, e José já não aparece mais entre os escravos desse proprietário. No ano de 1806, quando o escravo recebeu a dívida, consta na propriedade de Joaquim Carneiro Lobo um único cativo de nome José, de nação Angola, 39 anos, casado e, muito provavelmente, o vendedor do milho ${ }^{10}$. Na Lista Nominativa de 1820, ainda aparece um escravo de nome José, de 53 anos, viúvo, mas com a informação de que é crioulo, nascido na vila de Castro. Possivelmente se tratava do mesmo escravo de 1806, mas com um equívoco de quem preencheu a Lista no que se refere a origem de José, que antes vem referido como sendo um africano de Angola. Esses equívocos, no entanto, eram bastante comuns nas Listas Nominativas e devemos levar em conta que a idade do escravo confere, uma vez que se em 1806 estava com 39 anos, em 1820 estaria com 53, como informou o documento. Além disso, na primeira Lista ele aparece como sendo casado e na segunda, como viúvo, informação que podemos confirmar quando analisamos a Lista de 1806 e vemos que a única escrava casada era Inácia, uma crioula de 56 anos. José também era o único homem casado dentre os escravos, o que nos faz pensar que eram casados. Na Lista Nominativa de 1820, Inácia já não aprece mais, tendo provavelmente falecido, o que corrobora a informação de que José era viúvo.

É provável que José, após a morte de sua esposa, tenha comprado sua liberdade com o pecúlio que conseguiu reunir com a venda de sua produção excedente e, por esse motivo, não aparece mais entre os bens de Joaquim Carneiro Lobo em 1830. É claro: não devemos descartar a possibilidade de que o escravo tenha sido vendido ou então possa ter falecido.

O que vemos aqui, portanto, é um escravo cujo senhor permitia que roças independentes fossem cultivadas em sua propriedade, as quais deveriam servir tanto para a subsistência dos cativos como para a venda, quando havia excedente, como foi o caso de José. Francisco Carvalho de Oliveira, o comprador do milho, era um proprietário pouco abastado, possuía dois escravos e a soma de seus bens chegou a pouco mais de 500\$000 (quinhentos mil réis). Era possuidor de alguns poucos animais, sendo 14 cavalares, quatro vacuns e 35 ovinos, além de campos com terras para agricultura. Seu meio de subsistência deveria ser a agricultura, e talvez a venda de lã, bem como a fabricação de mantas e cobertores. O milho que comprou certamente era para alimentação dos animais e não foi apenas de José que Francisco comprou o cereal fiado. No inventário consta também como credor, e também por venda de milho, o importante proprietário Manoel Gonçalves Guimarães. Nesse caso, temos o produto de um escravo concorrendo com o de um abastado senhor, morador em Curitiba e dono de fazendas nos Campos Gerais. Talvez o cativo tenha feito um preço mais baixo do que o seu concorrente, o que acabou por conquistar o comprador. Devemos ressaltar também que a historiografia tem mostrado que os produtos cultivados pelos escravos eram normalmente vendidos para o senhor e não para uma terceira pessoa, como fez o cativo José. O Barão de Pati do Alferes, em 1847, alertava para esse fato afirmando: "não se deve consentir que a 
sua colheita [dos escravos] seja vendida a outrem, e sim a seu senhor, que deve fielmente pagar-lhe por um preço razoável, isto para evitar extravios e súcias de taberna” (SILVA, 1985, p. 37).

A permissão dada por Joaquim Carneiro Lobo para que seus cativos plantassem suas próprias roças certamente não era sem interesses. Os proprietários sabiam que se um escravo tivesse alguma forma de apego à terra em que vivia dificilmente fugiria e, portanto, o benefício compensava o custo. Mas, como bem ressaltou Slenes, não se pode ficar apenas com a visão dos senhores, é preciso pensar no que essa "concessão" mudou a vida dos escravos. No caso de José, recebeu como pagamento de sua dívida três carneiros, o que pode ter dado a ele novas possibilidades para conseguir algum lucro, já que agora poderia obter alguma lã e quem sabe até aumentar a criação. É bastante provável que o cativo tenha guardado o dinheiro recebido para comprar sua liberdade, talvez o "bem" mais almejado por ele. Mas, nem todos agiam dessa maneira.

São muitos os escravos que aparecem como devedores nos inventários, principalmente naqueles nos quais a venda de fazendas (tecidos) era a principal atividade. Francisco Machado da Silva, quando faleceu em 1803, tinha oito escravos lhe devendo, além de outras duas negras forras. Este senhor comercializava fazendas secas, ou seja, toda sorte de tecidos, além de roupas, navalhas, pentes e outros objetos. Não era só com a liberdade, portanto, que os escravos pensavam em gastar o que conseguiam acumular.

O fato, aqui estamos pensando, de Francisco Machado da Silva ter vendido mercadorias fiado para os escravos, sugere que ele sabia das condições dos compradores para pagar. E, a única forma de cativos conseguirem algum dinheiro era justamente através da permissão de seus senhores para vender produtos excedentes. Interessante ressaltar também que quatro dos oito escravos devedores a Francisco, eram pertencentes ao reverendo José Joaquim, o que pode indicar a permissão desse senhor para os escravos venderem a produção excedente, fosse da agricultura ou, quem sabe, até da criação. Apesar de não termos encontrado nenhuma evidência de que escravos tivessem também seu próprio rebanho, a região era bastante propícia a isso, sendo possível a compra de alguns animais com o dinheiro da lavoura, ou então, como no caso do escravo José, receber carneiros como pagamento de sua dívida e a possibilidade de iniciar uma criação.

Mas voltando às “compras" realizadas pelos escravos na venda de Francisco Machado da Silva, percebemos que eles também tinham as suas vaidades. Infelizmente não sabemos com precisão quais objetos foram adquiridos, mas certamente eram tecidos para a confecção de roupas, talvez algum enfeite para as mulheres, sapatos, enfim, coisas que, como cativos, não tinham acesso.

Outro escravo o qual aparece como devedor de Francisco Machado da Silva é Joaquim, pertencente à fazenda Pitangui. No inventário dessa propriedade realizado em 1806, do qual já falamos, o cativo está arrolado como tendo 67 anos de idade e uma das senzalas aparece como sendo habitada por ele, fato já observado. A Lista Nominativa de 1804 traz a informação de que 
Joaquim era casado, mas, na Lista de 1806, já aparece como viúvo. A única escrava casada que aparece em 1804 e não mais em 1806 é Domingas, o que nos faz pensar na possibilidade dela ser casada com Joaquim. Porém, há outro escravo, João, que também consta como casado em 1804 e viúvo em 1806, podendo também ser ele o marido de Domingas. Independente disso sabemos que quando fez a compra de Francisco Machado da Silva, em 1803, estava casado e deveria morar na senzala junto com sua esposa. O fato de Joaquim ter uma dívida no valor de $1 \$ 820$ (mil oitocentos e vinte réis) nos faz pensar que tinha alguma forma de conseguir seu próprio dinheiro, como os outros escravos dos quais falamos anteriormente. Ele ter o direito a uma senzala separada também pode ser uma pista de que os escravos de Pitangui tinham o direito de produzir e vender o excedente.

Em outro inventário temos um caso bastante peculiar. Um escravo chamado Pedro, pertencente a José Lopes de Toledo, aparece como credor de Francisco Alves de Oliveira, falecido em 1813. Seu senhor, o tal Toledo, também é credor do falecido, sem que fosse exposto o motivo da dívida. O valor devido a Pedro era pequeno, $\$ 600$ (seiscentos réis) e, para seu proprietário, 3\$040 (três mil e quarenta réis). Francisco Alves de Oliveira era dono de quatro escravos, dos quais dois foram leiloados para pagamento das dívidas. Pedro e José Lopes de Toledo tiveram seu pagamento proveniente de parte do valor da escrava Lauriana, arrematada em leilão. O que temos então é um escravo sendo pago por seus serviços com o valor de outra escrava. Ambiguidades da lei que se refletem no dia-a-dia. Se por um lado ela considerava o cativo uma propriedade, de outro permitia que essa mesma "propriedade" produzisse em benefício próprio e vendesse o excedente. E também aqui vemos o escravo vendendo seus produtos para uma terceira pessoa que não o seu senhor, contrariando as descobertas da historiografia, como o estudo de Robert Slenes que analisa um inventário em que os cativos da propriedade são credores de seu próprio senhor (SLENES, 1999, p. 205).

Os inventários, portanto, se mostraram boas fontes para investigar a "economia interna dos escravos", mesmo que indiretamente, como quando estes são apenas devedores. Mas o fato de termos cativos arrolados entre as dívidas ativas e passivas já mostra que muitos eram ativos economicamente e realizavam compras e vendas em seu próprio nome, fugindo por um momento da condição de propriedade para se tornarem proprietários, nem que fosse de uma simples peça de roupa. A historiografia costuma pensar a "economia interna dos escravos" sempre atrelada à compra da liberdade, mas o que encontramos em nossas fontes não indicam somente esse caminho. Os cativos também encontravam outros destinos para o seu pecúlio. Alguns escravos certamente conseguiram acumular uma maior quantia para então comprar sua liberdade, como pode ter sido o caso de alguns cativos de quem falaremos na próxima seção. No entanto, sem desprezar a importância da compra da alforria pelo próprio escravo e seu impacto no sistema escravista, devemos pensar que eles também almejavam coisas mais simples, como um par de sapatos, um 
pente, uma camisa e que, talvez, a maioria deles conseguiu "apenas" estas pequenas coisas; para eles certamente bens simbólicos e significativos.

A seguir falaremos de pessoas que conseguiram sair da condição de escravos para enfrentar novas dificuldades na vida em liberdade. Veremos que a "economia interna", trabalhada nesta seção, tem muito a ver com o assunto trabalhado a seguir, pelo menos em alguns casos.

\section{A liberdade}

Outra informação importante que encontramos nos inventários são as cartas de alforria concedidas ou requeridas pelos escravos. Quando eram concedidas pelos senhores, estes expressavam sua vontade em testamento e, quando era o próprio cativo quem requeria a liberdade, havia uma petição anexada ao processo de inventário. Como afirmou Chalhoub, a morte do senhor era um momento de esperança e de incerteza para o escravo. As chances de conseguir a liberdade existiam, porém, viviam momentos de incerteza, não sabendo ao certo seu destino, temendo serem separados de seus familiares e companheiros ou ainda de servirem a um novo senhor, como foi o caso de alguns cativos de quem falamos na primeira seção deste artigo (CHALHOUB, 1990, p. 111). Analisaremos agora situações dos dois tipos de alforrias, tanto concedidas como requeridas e, para alguns cativos, falaremos também dos rumos que deram para suas vidas após a liberdade.

Começaremos falando de Domingos, um crioulo de 30 anos pertencente a Manoel Ferreira Dias, este último falecido em 1819. Através de informações da Lista Nominativa de Habitantes de 1806, foi possível saber que esse escravo ia para o sul juntamente com seu senhor e outro cativo, quando então Domingos estava com 15 anos. Em 1819, quando seu senhor faleceu e foi feita a avaliação e partilha de bens, ele entrou com uma petição para a compra de sua liberdade, cujo processo está anexado ao inventário.

É nomeado um curador para Domingos que vai a juízo e afirma ter quem por ele deposite a quantia pela qual foi avaliado no inventário, ou seja, 128\$000 (cento e vinte e oito mil réis). A viúva e os herdeiros se recusaram a comparecer no juízo de órfãos para assinar a carta de liberdade e exigiram que o cativo fosse reavaliado, alegando ser o valor muito baixo. Domingos então foi reavaliado e seu valor subiu para $192 \$ 00$ (cento e noventa e dois mil réis). O curador Bernardo José Gomes depositou a diferença da primeira avaliação do escravo e, finalmente, a família concordou em assinar a carta de liberdade de Domingos.

Provavelmente os herdeiros e o escravo não chegaram a um acordo quanto ao preço que valia e por isso Domingos levou o caso ao juízo. Como os cativos não tinham "personalidade jurídica", era necessária a nomeação de um curador para representá-los. Por isso a afirmação de que Domingos tinha quem por ele depositasse a quantia em juízo. O curador apenas o representava, mas quem oferecia a quantia era o próprio escravo. E aqui devemos mais uma vez pensar na "economia 
interna dos escravos". Domingos conseguiu reunir a quantia significativa de quase $200 \$ 000$ (duzentos mil réis), provavelmente provenientes de uma produção independente que ele mantinha na condição de escravo. $\mathrm{O}$ fato de ele ir para o sul com seu senhor nos faz pensar que conquistou a confiança de seu proprietário, isso pode ter lhe facilitado a permissão para cultivar uma roça ou criar animais em benefício próprio.

Outro escravo que vai a juízo para requerer sua liberdade é Miguel, pertencente a José Rodrigues Betim. Este caso é um pouco diferente do de Domingos, pois, na sua petição, diz-se que

na presente ocasião é arrematado em praça pública pela quantia constante dos lances do porteiro deste juízo para benefício das dívidas de seu falecido senhor e por que tem quem lhe faça a esmola de dar-lhe a sua valia para que fique gozando de sua liberdade tão recomendada pelas leis de S.A.R [Sua Alteza Real] requer a V.mce. que por caridade lhe aceite a quantia por que é arrematado e se lhe faça o termo de recebimento ficando o suplicante gozando de sua liberdade e livre do cativeiro $^{11}$.

Não consta no processo nenhum nome de curador e, ao que parece, não seria Miguel quem iria pagar por sua liberdade, pois o mesmo afirma que "tem quem lhe faça a esmola", ao contrário do cativo Domingos. Infelizmente não sabemos quem era essa pessoa caridosa e quais as condições impostas para que o escravo recebesse a alforria. Uma possibilidade é a pessoa que libertou Miguel ser algum parente já liberto que conseguiu reunir a quantia necessária para comprar sua liberdade, talvez a mãe ou o pai, ou até mesmo uma companheira, apesar de aparecer na Lista Nominativa de 1806 como solteiro. Miguel seria arrematado por Cirino Borges de Macedo pela quantia de 26\$000 (vinte e seis mil réis), valor muitíssimo baixo para um escravo que deveria estar com aproximadamente 40 anos de idade.

Temos um caso de uma liberta que comprou a alforria de seus dois filhos pequenos. Trata-se de Rita, solteira, mas mãe de dois meninos. Rita pertencia a Manoel Lopes Branco e Silva e foi libertada ainda quando seu senhor era vivo. Depois disso, a escrava foi para a cidade de São Paulo "tratar de sua vida", como ela mesma afirma na petição anexada ao inventário. Com o dinheiro que conseguiu trabalhando, comprou a alforria de seus dois filhos, os quais havia deixado com a viúva de seu falecido senhor, Maria Lúcia de Menezes. Ao que parece, mesmo depois de ter libertado seus filhos Raimundo e Pedro, Rita continuou sozinha em São Paulo, deixando os meninos com a viúva. Sobre isso, Rita afirma que quando retornou para a vila de Castro, soube da morte de seu senhor e que seus dois filhos haviam sido avaliados e seriam usados para pagamento de dívidas do inventário. Resumindo, a liberdade de Rita, e de Raimundo e Pedro, foi reconhecida pela viúva e pelo testamenteiro, Luciano Carneiro Lobo, casado com a filha de Manoel Lopes Branco e Silva. Foi Luciano quem enviou um pedido ao juiz para que os dois meninos fossem avaliados, alegando que haviam ficado de fora da avaliação. Interessado na herança que lhe cabia, tentou incluir Pedro e Raimundo na partilha, aumentando assim o valor dos bens de seu falecido sogro e, 
consequentemente, sua própria fortuna. Chalhoub também encontrou em suas pesquisas casos de herdeiros que se recusavam a admitir a vontade do inventariado de libertar seus escravos e faziam de tudo para que a alforria não fosse concedida, mostrando a "avareza" entre os herdeiros, algo bastante comum (CHALHOUB, 1990, p. 115).

Mas o que vemos então é que Rita, após a liberdade, foi buscar oportunidades longe da vila de Castro, na cidade de São Paulo. Talvez a ideia da ex-escrava fosse apenas conseguir algum pecúlio e voltar para Castro, uma vez que não levou seus filhos consigo. Segundo uma carta de liberdade apresentada por Rita em 1815, ela comprou a liberdade de seus filhos em 1812 e, naquele ano ela ainda estava em São Paulo, enquanto Raimundo e Pedro continuavam sob os cuidados de sua exsenhora, ameaçados de serem vendidos ilegalmente. Sabemos que em 1815 Rita ainda estava em São Paulo porque ela fez a queixa contra a venda ilegal de seus filhos no cartório desta cidade e não na vila de Castro. Parece que Rita resolveu o problema mesmo estando longe.

Não foi apenas Rita que buscou novas oportunidades em outras vilas da capitania e depois província de São Paulo. Outros escravos que conquistaram sua liberdade também decidiram abandonar a vila de Castro. Foi o caso de alguns dos sete escravos libertados em testamento por Francisco Xavier da Silva, proprietário da fazenda Caxambu, em 1829. Três destes escravos eram africanos, sendo um de 'nação' monjolo, chamado José; outro, de nome Bernardo, o qual já estava há bastante tempo em poder de Xavier da Silva, constando seu nome na Lista Nominativa de 1806, com 21 anos, solteiro, procedente de Benguela; e Josefa, que igualmente a Bernardo, já pertencia a Xavier da Silva em 1806, quando tinha 29 anos, estava casada e era procedente de Angola ${ }^{12}$. Os três escravos eram, portanto, procedentes da África Centro-Ocidental, e falantes de algum idioma do tronco linguístico banto.

O marido de Josefa, Joaquim, crioulo, natural de Itu, seria libertado juntamente com sua mulher. Porém, Xavier da Silva, em seu testamento, revoga sua carta de liberdade, afirmando que “[...] este dito tem desmerecido muito por vários desgostos que me tem dado e minha última vontade é destratar neste meu testamento a dita carta [...]"13. O casal José e Bárbara, ambos crioulos, também receberam carta de liberdade. Os crioulos Antonio e Clara foram os outros dois escravos libertados.

Através do auto de contas de testamento, foi possível saber um pouco sobre a vida em liberdade de Clara e de José, o africano. Uma vez que eles, depois da morte de Xavier da Silva, saíram da Vila de Castro, o testamenteiro Francisco José de Mattos precisou que algumas testemunhas confirmassem que ambos haviam sido postos em liberdade. Uma dessas testemunhas era um ex-escravo de Francisco Xavier da Silva, também um liberto. Vale a pena, antes de entrarmos nas vidas de Clara e José, discorrer brevemente sobre esse homem, tendo em vista que viveu nas terras da fazenda Caxambu e levou consigo, após sua liberdade, toda a experiência 
adquirida nessa propriedade.

José Duarte da Costa era um homem pardo, casado, de mais ou menos 60 anos, natural de Pernambuco, morador na Vila de Castro e que afirmou viver "de suas lavouras"14. Não foi possível descobrir quando José obteve sua liberdade, mas na Lista Nominativa de 1810 ele aprece como cativo de Xavier da Silva, com 50 anos e casado ${ }^{15}$. As informações de seu depoimento, e também da Lista Nominativa, mostram que, provavelmente, ele veio para a província de São Paulo pelo tráfico interno, uma vez que era pernambucano. Talvez Xavier da Silva o tenha comprado em uma de suas viagens a negócios para Sorocaba, como havia feito no ano de 1803, quando comprou dois escravos naquela localidade (LOPES, 2001, p. 115). Esse caso demonstra mais uma vez a interdependência que havia entre as áreas abastecedoras e as consumidoras, afinal, o proprietário de Castro vendia gado em Sorocaba e lá adquiria outros bens, como escravos, por exemplo.

Retomando o caso de José, o africano libertado, observamos no auto de contas de testamento todas as testemunhas confirmarem que ele, após a morte de seu senhor, foi posto em liberdade e seguiu para a Comarca de Itu, onde estava vivendo de "seus negócios", conforme é descrito no documento. A respeito de Clara, todas as testemunhas afirmam que ela recebeu sua carta de liberdade ainda quando Xavier da Silva estava vivo e, depois da morte de seu senhor, seguiu para Taubaté, na Comarca de São Paulo. Clara era casada com José, também escravo de Xavier da Silva, natural de Curitiba e que em 1806, ano em que Clara foi comprada, já residia em Caxambu. Os dois se casaram neste mesmo ano, ele com 23 anos e ela com 24. Pelas informações conseguidas nos documentos, o marido de Clara não obteve a liberdade e, provavelmente, a ex-escrava foi para Taubaté sozinha.

Francisco José de Mattos, o testamenteiro, afirma que "Clara Maria, já em vida do testador, se achava no gozo de sua liberdade e continuando a prestar serviços ao mesmo, ele lhe deixou um legado remuneratório" ${ }^{\prime 16}$. Era prática comum os senhores concederem liberdade condicional a seus escravos, ou seja, lhes passavam as cartas de alforria, mas lhe impunham as condições mais diversas, como a continuidade de prestação de serviços ao senhor, até a morte deste. Kátia Mattoso afirma ser essa a condição mais comum imposta aos escravos e não é difícil imaginar que esse tipo de liberdade condicional era concedida a cativos já em uma idade mediana, arriscados a falecer antes do senhor (MATTOSO, 1988, p. 208).

Clara, segundo a lista nominativa de 1825, estava com 40 anos, ou seja, em 1829, ano em que Xavier da Silva fez seu testamento, estaria com aproximadamente 44 anos. É uma idade mediana. Porém, a hipótese levantada por Mattoso, não se aplica nesse caso, pois o senhor de Clara estava com uma idade muito mais avançada do que a dela e também porque o testamenteiro, Francisco José de Mattos, afirma que Xavier da Silva deixou um "legado remuneratório" para a escrava pelo tempo trabalhado após ter recebido sua carta de liberdade. Ao que parece, Clara recebeu sua carta 
de alforria sem que seu senhor impusesse qualquer condição e, provavelmente, entre os anos de 1825 e 1829, uma vez que na lista nominativa de 1825 ainda aparece como cativa e no testamento de Xavier da Silva, de 1829, este escreve:

declaro mais por minha última vontade deixar liberta a minha escrava Clara, mulata, [...] a qual dita mulata eu havia passado carta de liberdade de meu punho e lhe havia entregado e receando a dita [escrava] ter perdido a dita carta, faço esta declaração ${ }^{17}$.

Portanto, Clara havia recebido sua carta de liberdade antes de Xavier da Silva fazer seu testamento.

A liberdade concedida, contudo, poderia ser revogada pelos senhores se eles assim desejassem, como fez Xavier da Silva com seu escravo Joaquim; revogou sua carta de liberdade, a qual já havia sido registrada em tabelionato, alegando que o escravo estava lhe causando “desgostos”. A revogação de alforria foi permitida até 1865, quando então os tribunais declararam tal procedimento inadmissível. Porém, se fosse por motivo de ingratidão, a carta de liberdade poderia ser anulada, conforme estava previsto no título 13 do livro $4^{\circ}$ das Ordenações Filipinas do século XVII (MATTOSO, 1988, p. 180). Conforme nos conta Chalhoub,

a ingratidão do liberto estava configurada se ele ferisse ou apenas tentasse ferir o ex-senhor, se o prejudicasse na sua fazenda, se o deixasse de socorrer em caso de fome ou necessidade, ou se proferisse injúrias verbais contra o patrono mesmo na sua ausência (CHALHOUB, 1990, p. 137).

A carta de alforria de Joaquim, no entanto, foi revogada em 1829, quando ainda era permitida sem nenhuma restrição. Fica difícil, portanto, sabermos ao certo que "desgostos" o escravo causou ao seu senhor.

Os destinos de Clara e José, após obterem suas cartas de liberdade, podem ser um indício de que quando eram escravos de Xavier da Silva, acompanhavam seu senhor nas viagens para negociar tropas na feira de Sorocaba. Nestas, provavelmente, mantinham contatos com pessoas da região e constituíam vínculos, o que possibilitou que fossem para Itu e Taubaté após obterem suas cartas de liberdade. Clara, porém, era natural de Taubaté, foi comprada nesta vila por Xavier da Silva, quando já tinha 24 anos. Isto talvez explique o fato da escrava retornar para a sua vila, talvez em busca de parentes; e lá se viu forçada a deixar e seguir para a vila de Castro, quando de sua venda ao proprietário de Caxambu.

Taubaté estava localizada no Vale do Paraíba e era uma parada para descanso e engorda dos animais antes de seguirem para as áreas consumidoras, como Rio de Janeiro e Minas Gerais, o que explica o fato de Xavier da Silva manter negócios com proprietários dessa região (TRINDADE, 1992, p. 40). O escravo Joaquim, o qual teve sua liberdade revogada, era natural de Itu, sendo possível que Xavier da Silva o tenha comprado nesta localidade, confirmando a intensa ligação 
entre as vilas da província paulista e também a consequente rede de relações construída também pelos escravos que transitavam nesses caminhos.

Apresentamos, portanto, algumas situações vivenciadas por escravos de Castro que partilharam, juntamente com o restante da população, a experiência de viver em uma região voltada para a criação de gado e a prática do tropeirismo e, principalmente, caracterizada por ser uma "zona de trânsito" e, talvez por isso, mais propensa à mobilidade espacial da comunidade. Vimos que alguns cativos fizeram bom uso dessa mobilidade, fosse fugindo, vendendo produtos para os viajantes que por ali passavam ou mesmo buscando novas oportunidades após a liberdade.

\section{Referências Bibliográficas}

CARDOSO, C. Agricultura, escravidão e capitalismo. Petrópolis: Vozes, 1979.

. Escravo ou camponês: o protocampesinato negro nas Américas. São Paulo: Brasiliense, 1987.

CHALHOUB, S. Visões da Liberdade. Uma história das últimas décadas da escravidão na corte. São Paulo: Companhia das Letras, 1990.

COSTA, I. del N.; GUTIÉRREZ, H. Paraná: mapas de habitantes, 1798-1830. São Paulo: IPE, 1985.

DINIZ, J. M.F, et. al. Cronologia: Castro Antiga. Curitiba: Imprensa Oficial, 2003.

FERREIRA, J. C. V. Municípios paranaenses: origens e significados de seus nomes. Curitiba: Secretaria de Estado da Cultura, 2006.

GORENDER, J. O escravismo colonial. São Paulo: Ática, 1985.

LOPES, J. C. V. Origens do povoamento de Ponta Grossa. J.C.V.L: Curitiba, 2001.

MARCÍLIO, M. L. Crescimento demográfico e evolução agrária paulista: 1700-1836. São Paulo: Hucitec, Edusp, 2000.

MARCONDES, R. L. Formação da rede regional de abastecimento do Rio de Janeiro: a presença dos negociantes de gado. (1801-1811). Topoi, Rio de Janeiro, n. ${ }^{\circ}$ 2, mar. 2001, 41-71.

MATTOSO, Kátia de Queirós. Ser escravo no Brasil. São Paulo: Brasiliense, 1988.

SILVA, E. "O Barão de Pati do Alferes e a fazenda de café da velha província”. Introdução a: Pati do Alferes, Francisco Peixoto de Lacerda Werneck, Barão de. Memória sobre a fundação de uma fazenda na província do Rio de Janeiro. Rio de Janeiro/Brasília: Fundação Casa de Rui Barbosa/Senado Federal, 1985.

SLENES, R. Na Senzala, uma flor. Esperanças e recordações da família escrava - Brasil Sudeste, século XIX. Rio de Janeiro: Nova Fronteira, 1999. 
THOMPSON, E. P. A formação da classe operária inglesa. Rio de Janeiro: Paz e Terra, 1987.

TRINDADE, J. B. Tropeiros. São Paulo: Editoração, Publicações e Comunicações Ltda., 1992.

WESTPHALEN, C. M. Afinal, existiu ou não regime escravo no Paraná? Revista da SBPH, $\mathrm{n}^{\circ} 13$ : 25-63, 1997.

. Paraná - Zona de Trânsito. Boletim do Instituto Histórico, Geográfico e Etnográfico

Paranaense. Curitiba, $\underline{8}:$ 45-55, 1957.

\section{NOTAS}

${ }^{1}$ Existe um levantamento das fazendas e sítios dos Campos Gerais feito em 1772 por Afonso Botelho em que constam as propriedades formadas por absenteítas, que contavam com um fazendeiro e, muitas vezes, um escravo para administrar a fazenda. Citado por WESTPHALEN, C. M. Afinal, existiu ou não regime escravo no Paraná? Revista da $S B P H, \mathrm{n}^{\circ} 13$, p. 25-63, 1997. pp. 52-53.

${ }^{2}$ A porcentagem de escravos na população de Castro durante a primeira metade do século XIX se assemelhou, proporcionalmente, a de Pernambuco na década de 1760. De acordo com um mapa geral de 1762, os escravos em Pernambuco representavam 25,8\% da população. (Biblioteca Nacional do Rio de Janeiro. Divisão de manuscritos. Mapas Estatísticos da Capitania de Pernambuco. 3, 1, 38, fl. 01.)

${ }^{3}$ Para mais informações sobre o episódio de Capão Alto ver PENA, E. S. Burlas à lei e revolta escrava no tráfico interno do Brasil meridional, século XIX. In: Silvia Hunold Lara; Joseli Mendonça. (Org.). Direitos e Justiças no Brasil. Ensaios de História Social. Campinas, SP: Editora da Unicamp, 2006.

${ }^{4}$ Lista Nominativa de Habitantes, Castro - 1810. Cópia do CEDOPE/UFPR (Originais no AESP).

${ }^{5}$ Lista Nominativa de Habitantes, Castro - 1798. Cópia do CEDOPE/UFPR (Originais no AESP).

${ }^{6}$ Lista Nominativa de Habitantes, Castro - 1804. Cópia do CEDOPE/UFPR (Originais no AESP).

7 Inventário de bens da fazenda Pitangui, 1806. Vara Cível de Castro.

8 Inventário post mortem de Ignácio Rodrigues da Silva, 1800. Vara Cível de Castro.

9 Lages hoje é município do estado de Santa Catarina e está a 358 km de Curitiba.

${ }^{10}$ Lista Nominativa de Habitantes, Castro - 1806. Copia do CEDOPE/UFPR (Originais no AESP).

${ }^{11}$ Inventário post-mortem de José Rodrigues Betim, 1811. Vara Cível de Castro.

${ }^{12}$ Lista Nominativa de Habitantes, Castro - 1806. Copia do CEDOPE/UFPR (Originais no AESP).

${ }_{13}^{13}$ Auto de Contas de testamento - Castro, 1832. DEAP. JP 1924, cx. 91.

${ }^{14}$ Idem.

${ }^{15}$ Percebemos aqui a imprecisão dos documentos no que diz respeito às idades informadas para José, visto que se em 1810 ele estava com 50 anos, em 1832 já estaria com mais de 70.

${ }^{16}$ Auto de Contas de testamento - Castro, 1832. DEAP. JP 1924, cx. 91.

${ }^{17}$ Auto de Contas de testamento - Castro, 1832. DEAP. JP 1924, cx. 91.

Artigo recebido em 01/2010. Aprovado em 04/2010. 